\title{
Morphometric evaluation of the styloid process of the temporal bone as an aid in age and sex discrimination - A retrospective digital panaromic study
}

\author{
Varsha Kanjani ${ }^{1, *}$, Abha Rani², Deepak Kanjani ${ }^{3}$ \\ ${ }^{1,2}$ Post Graduate Student, ${ }^{3}$ Medical Officer, Dept. of Oral Medicine and Radiology, ${ }^{\mathbf{1}, 2}$ College of Dental Sciences, Davangere, Karnataka, \\ ${ }^{2}$ Fidusar, Government Hospital, Jodhpur, Rajasthan, India
}

*Corresponding Author: Varsha Kanjani

Email: varshakanjani0@gmail.com

\begin{abstract}
Introduction: Maxillofacial radiology plays a significant role in forensic anthropology for age and sex discrimination in case of mass disasters. Anatomically, Styloid process is bony structure; cylindrical in shape arises from the temporal bone which tapers gradually towards apex. A careful clinical and radiological examination can lead to early detection of its length, anatomic variations and elongation. Therefore, morphometric analysis of length of the styloid process can be one of the adjuvant tools for age and sex discrimination in forensic anthropology.

Aim: To evaluate the length and anatomic variations of the styloid process as an aid in age and sex discrimination using digital panaromic radiographs.

Materials and Methods: Digital panaromic radiographs of 3800 individuals were randomly taken from private diagnostic clinic's database.

All the panaromic radiographs were evaluated for the radiographic length and anatomic variations of the styloid process bilaterally using measuring tool inbuild in the software. The obtained data was analyzed using SPSS software version 21.0.

Results: The mean lengths of the styloid processes were statistically significant as the age advances and also in males and females bilaterally ( $\mathrm{p}$ value $<0.05$ ) with the prevalence rate of elongated process reported as $22.47 \%$.

Conclusion: The morphometric evaluation of the styloid process of the temporal bone can be used as an adjuvant in age and sex discrimination using digital panaromic radiograph.
\end{abstract}

Keywords: Digital panaromic radiography, Eagle's syndrome, Forensic anthropology, Morphometric analysis, Styloid process.

\section{Introduction}

The human skull plays a significant role in forensic anthropology as it contains various unique anatomical structures such as frontal sinus, nasal septum, sella turcica, orbital aperture, styloid process, vascular groove patterns, etc. ${ }^{1-4}$ Among all, the styloid process is underrated. ${ }^{5}$ The styloid process of the temporal bone is slender bony anatomical structure, measures approximately $25-30 \mathrm{~mm}$. In males and females, the length of the styloid process of the temporal bone differs, thereby can be used as an adjuvant for sex discrimination in case of mass disasters such as cyclones, tsunamis, earthquacks, bomb blasts, etc. ${ }^{6,7}$ Elongated styloid process well-known as Eagle's syndrome or Stylalgia is mainly characterized by head and neck pain, dysphagia, odynophagia and increased salivation. ${ }^{8-10}$

The maxillofacial radiology helps to determine the sex using ante-mortem radiographs. On comparing with the post-mortem radiographs, the personal and sex determination can be established in case of dead, deceased or decayed human remains and living individuals. Therefore, in the present study,

1. The length of the styloid process was evaluated for gender discrimination using digital panaromic radiographs

2. Determine the prevalence of the elongated styloid process in the present population.

\section{Materials and Methods}

The present retrospective study included 3800 digital panaromic radiographs (1900 males and 1900 females) taken between January and September 2018 were randomly selected between 18 to 60 age group from private diagnostic clinic's database, Rajasthan. The panaromic radiographs taken with improper technique, patients positioning errors, magnification errors, artifacts or superimposed anatomical structures were excluded from the study while the radiographs taken with proper positioning technique without superimposed structures were taken in the study. As it is retrospective study, the ethical clearance was not applicable.

All the radiographs were taken using PLANMECA machine and ROMEXIS software under standard exposure parameters. The radiographic length of the styloid process was measured from the point from where the styloid process leaves the tympanic plate to the apex bilaterally using measurement tool of the software (Fig. 1). The length more than $30 \mathrm{~mm}$ were considered as elongated, irrespective of ossification of the styloyoid ligament or segmentation and were classified radiographically according to Langlais and Langland. ${ }^{11}$ The obtained data was analyzed using SPSS software (version 21.0) using t-test and Chi square test.

\section{Results}

The present study reported the mean length of styloid process was greater in males as compared to females bilaterally ( $\mathrm{p}$ value $<0.05$ ). The mean length of left and right styloid process in males was reported as $27.12 \pm 5.47$ $\mathrm{mm}$ and $26.82 \pm 6.28 \mathrm{~mm}$ while in females was $25.38 \pm$ $5.26 \mathrm{~mm}$ and $25.16 \pm 6.98 \mathrm{~mm}$ respectively (Table 1 ).

The length of the styloid process increases significantly with age with $\mathrm{p}$ value less than 0.05 . As the age advances, 
the length of the styloid process increases. The maximum number of individuals belongs to the second decade followed by fourth (Table 2). On evaluating 3800 panaromic radiographs, $854(22.47 \%)$ showed elongated styloid processes. Out of which 542 (14.2\%) and $312(8.21 \%)$ showed right and left elongated styloid process respectively.

Table 1: The mean length of the left and right styloid process in males and females

*statistically significant

\begin{tabular}{|l|c|c|c|}
\hline \multirow{2}{*}{ Gender } & \multirow{2}{*}{\begin{tabular}{c} 
n \\
\cline { 3 - 4 }
\end{tabular}} & \multicolumn{2}{c|}{ Mean Length of Styloid Process $(\mathbf{m m})$} \\
\cline { 3 - 4 } & $1900(50 \%)$ & $27.12 \pm 5.47$ & Reft side \\
\hline Males & $1900(50 \%)$ & $25.38 \pm 5.26$ & $26.82 \pm 6.28$ \\
\hline Females & & $0.001^{*}$ & $0.000^{*}$ \\
\hline
\end{tabular}

Table 2: The mean length of the styloid processes in different age groups.

\begin{tabular}{|l|c|c|c|}
\hline \multirow{2}{*}{ Age } & \multirow{2}{*}{$\begin{array}{c}\text { n } \\
\end{array}$} & $(\boldsymbol{\%})$ & Mean Length of Styloid Process (mm) \\
\cline { 3 - 4 } & $482(12.68 \%)$ & $21.98 \pm 4.65$ & Right side \\
\hline $18-20$ & $1167(30.71 \%)$ & $24.58 \pm 5.73$ & $22.17 \pm 4.18$ \\
\hline $21-30$ & $852(22.42 \%)$ & $25.61 \pm 5.21$ & $24.14 \pm 5.42$ \\
\hline $31-40$ & $1008(26.52 \%)$ & $25.94 \pm 5.25$ & $25.32 \pm 5.85$ \\
\hline $41-50$ & $291(7.65 \%)$ & $26.26 \pm 5.10$ & $25.79 \pm 5.37$ \\
\hline $51-60$ & & $0.017 *$ & $26.47 \pm 5.82$ \\
\hline p value & & \multicolumn{2}{c}{$0.03 *$} \\
\hline
\end{tabular}

*statistically significant

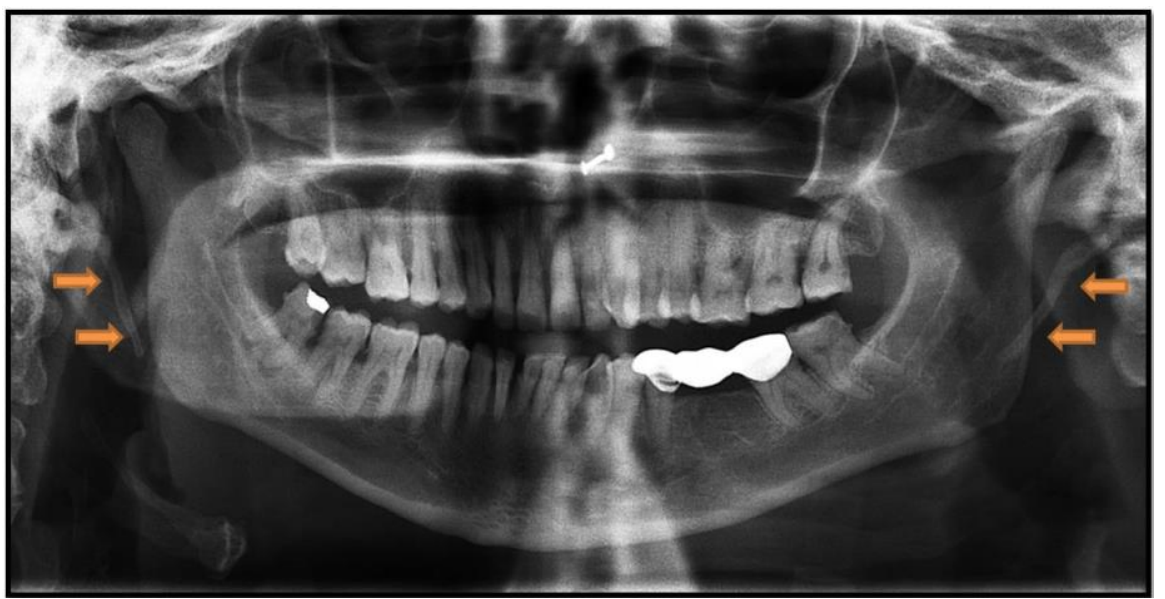

Fig. 1: Panaromic radiograph presenting the styloid process of the temporal bone bilaterally (Orange arrows)

\section{Discussion}

The styloid process of the temporal bone is one of the unique structures present in the human skull which can be used for age and sex discrimination in forensic anthropology. Theories proposed in the literature such as reactive hyperplasia, metaplasia, developmental anamoly, anatomic variations, etc. explained segmentation of the bony structure and its ossification with stylohyoid or stylomandibular ligaments. ${ }^{12-14}$

Various imaging modalities have been used for analyzing styloid process of the temporal bone such as anterioposterior skull radiograph, lateral skull radiograph, Town's view radiograph, and CBCT, etc. ${ }^{15-17}$ Three dimensional CT scan is the best radiographic modality to evaluate its length and angulation but in the present study, digital panaromic radiographic view was used as it is frequently prescribed by the dental professionals along with its low cost, lesser radiation exposure and extensive visualization of oral and maxillofacial structures including styloid process. ${ }^{18,19}$

The mean styloid process length as reported by Eagle (1937) was $25-30 \mathrm{~mm} .^{20,21}$ The present study stated that the styloid process are longer in males than females and also increases as the age advances. A study conducted by Balcioglu et al. ${ }^{22}$ in 2009 on human dry skulls stated that the lengths are longer in males than females and also increases as the age advances. Another study conducted in 2011 on human dry skulls concluded the statistically significant differences between genders. ${ }^{23}$

A radiographic study conducted by More et $\mathrm{al}^{24}$ in 2010 on 500 panaromic radiographs reported the mean left and right length as $25.41 \pm 6.32 \mathrm{~mm}$ and $25.53 \pm 6.62 \mathrm{~mm}$ which is in context with the present study. The authors further concluded that males have larger styloid processes 
than females and their length increases with advancing age. Hassan et $\mathrm{al}^{25}$ conducted similar study considering the importance of the styloid process stating that it is highly significant in assessing the gender in Iraqi population with $p$ value less than 0.001 . Another study published on Turkish population using panaromic radiographs stated the significant gender difference between the styloid processes lengths. The same study also concluded that there is significant differences even in age sub groups which are in accordance with the present study. ${ }^{26}$

On the contrary, Bruno et al. ${ }^{27}$ in 2017 conducted an epidemiological study using 1003 panaromic radiographs stating that there is zero correlation between age and the length of styloid process. Similar study conducted by Magat et $\mathrm{al}^{28}$ on 910 panaromic radiographs concluded no significant difference between styloid process characteristics, gender and age. The retrospective radiographic studies were conducted using 208 and 1000 CBCT's reported that there is no corelation between the styloid processes and genders. Authors even concluded CBCT as one of the alternative to other imaging modalities in the assessment of the styloid processes. ${ }^{29,30}$

Till our knowledge, this is first study conducted on Rajasthan population evaluating the styloid processes prevalence. In the present study, $854(22.47 \%)$ radiographs showed elongated styloid processes. Out of which, 542 $(14.2 \%)$ and $312(8.21 \%)$ showed right and left elongated styloid process respectively. The present study is in accordance with the study published by More and Asrani ${ }^{24}$ showed elongated styloid process in $19.4 \%$ individuals. A study published on South Indian population ${ }^{31}$ reported with $24.8 \%$ prevalence and another similar study conducted in Mathura $^{32}$, stated the peak occurrence of $52.1 \%$ in Northern population. Another panaromic study conducted on Turkish population stated only $7.7 \%$ prevalence of the styloid process. ${ }^{26}$ Ilguy et $a l .{ }^{33}$ on evaluating the 860 panaronic radiographs concluded that $3.7 \%$ while Erol et al.$^{34}$ reported only $1.1 \%$ prevalence of the elongated styloid process. The greater predominance of elongated styloid process in the present study can be attributed to the dietary habits i.e. chewing hard food or arecanut, sternous exercises or workload, etc.

The present study reported the prevalence of the elongated styloid process and its significance in Rajasthan population. In the present study, smaller sample size was taken along with use of panaromic radiographs. Therefore, larger sample size along with advanced radiographic modality such as three dimensional CT scan is recommended for precise dimension of the styloid process.

\section{Conclusion}

The morphometric analysis of the styloid process of the temporal bone can be used as an adjuvant in age and sex discrimination using digital panaromic radiograph.

\section{Acknowledgement: Nil}

\section{Conflict of Interest: Nil.}

\section{References}

1. Trant M, Christensen AM. Frontal Sinus Absence Rates in Various Populations: Implications for Forensic Identification. Forensic Anthropol. 2018;1(2):99-104.

2. Verma P, Verma KG, Khosa R, Kumar S, Basavaraju S, Patwardhan N. Combined use of frontal sinus and nasal septum patterns as an aid in forensics: A digital radiographic study. N Am J Med Sci. 2015;7(2):47.

3. Kiran CS, Ramaswamy P, Santosh N, Smitha B, Satish A. Radio-morphometric analysis of sella turcica in the South Indian Population: a digital cephalometric study. Arab J Forensic Sci Forensic Med (AJFSFM). 2017;1(5).

4. Ghorai L, Asha ML, Lekshmy J, Rajarathnam BN, Kumar HM. Orbital aperture morphometry in Indian population: A digital radiographic study. J Forensic Dent Sci. 2017;9(2):61.

5. Borah BK, Saikia R, Bhuyan J. Morphological study of the styloid process of temporal bone in the population of NorthEast India. J Evol Med Dent Sci. 2017;6(27):2213-2217.

6. Amorim JM, Pereira D, Rodrigues MG, Beato-Coelho J, Lopes M, Cunha A, Figueiredo S, Mendes-Pinto M, Ferreira C, Sargento-Freitas J, Castro S. Anatomical characteristics of the styloid process in internal carotid artery dissection: Casecontrol study. Int J Stroke. 2018;13(4):400-5.

7. Meza SC, Ortiz CJ, Caballero AD. Elongation of the Styloid Process, Dental Implications. Literature Review and Presentation of 5 Clinical Cases. J Dent Oral Care. 2016;2(4).

8. Maki D, Okami K, Ebisumoto K, Sakai A. Chronological Progression of an Enlarged Styloid Process: A Case Report of Eagle Syndrome. Case reports in otolaryngology. 2018;2018.

9. Levy T, Bader S, Hermann KG, Yaniv G, Grinberg G, Mozes O, Lidar M, Eshed I. Styloid Process Elongation on Cervical Spine Computed Tomography is Associated with the Enthesopathy-Related Diseases of Ankylosing Spondylitis and Diffuse Idiopathic Skeletal Hyperostosis. Isr Med Assoc J: IMAJ. 2017;19(11):670-673.

10. Soylu E, Altan A, Sekerci AE, Akbulut N. An Asymptomatic and Overelongated Styloid Process. Case Rep Dent. 2017;2017.

11. Langlais RP, Langland OE, Nortje CJ. Soft tissue radiopacities. In Langlais RP, Langland OE(edi) Diagnostic imaging of the jaws. Philadelphia: A Lea and Febiger. 1995. p.617-21.

12. Jaju PP, Suvarna P, Parikh N. Eagles syndrome. An enigma to dentists. J Indian Acad Oral Med Radiol. 2007;19:424429.

13. Steinman EP. Styloid syndrome in absence of an elongated process. Acta Otolaryngol.1968;66:347-356.

14. Camarda AJ, Deschamps C, Forest D. I. Stylohyoid chain ossification: A discussion of etiology. Oral Surg Oral Med Oral Pathol. 1989;67:508-514.

15. Okabe S, Morimoto Y, Ansai T, Yamada K, Tanaka T, Awano S, et al. Clinical significance and variation of the advanced calcified stylohyoid complex detected by panoramic radiographs among 80-year-old subjects. Dentomaxillofac Radiol. 2006;35(3):191-99.

16. Basekim CC, Mutlu H, Güngör A, Silit E, Pekkafali Z, Kutlay M, et al. Evaluation of styloid process by threedimensional computed tomography. Eur Radiol. 2005;15(1):134-39.

17. Shaik MA, Naheeda, Kaleem SM, Wahab A, Hameed S. Prevalence of elongated styloid process in Saudi population of Aseer region. Eur J Dent. 2013;7(4):449-54.

18. de Andrade KM, Rodrigues CA, Watanabe PCA, Mazzetto MO. Styloid process elongation and calcification in subjects with TMD: clinical and radiographic aspects. Braz Dent $J$. 2012;23(4):443-50. 
19. Ekici F, Tekbas G, Hamidi C, Onder H, Goya C, Cetincakmak MG, et al. The distribution of stylohyoid chain anatomic variations by age groups and gender: an analysis using MDCT. Eur Arch Otorhinolaryngol. 2013;270(5):171520.

20. Eagle WW. Elongated styloid processes: Report of two cases. Arch Otolaryngol. 1937;25:584-587.

21. Kaufman SM, Elzay RP, Irish EF. Styloid process variation. Radiologic and clinical study. Arch Otolaryngol. 1970;91:460-463.

22. Balcioglu HA, Kilic C, Akyol M, Ozan H, Kokten G. Length of the styloid process and anatomical implications for Eagle's syndrome. Folia Morphologica. 2009;68(4):265-270.

23. Saheb HS, Shepur MP, Haseena S. Study the length of styloid process in South Indian adults dry skulls. J Pharm Sci Res. 2011;3(9):1456.

24. More CB, Asrani MK. Evaluation of the styloid process on digital panoramic radiographs. The Indian journal of radiology \& imaging. $2010 \mathrm{Nov} ; 20(4): 261$.

25. Hassan NA. Comparative panoramic study of the elongated styloid process between male and female, their possible associations with age and Eagle's syndrome symptoms in Iraqi dentulous subjects. Mustansiriya Dent J. 2018;12(1):116-125.

26. Gokce C, Sisman Y, Ertas ET, Akgunlu F, Ozturk A. Prevalence of styloid process elongation on panoramic radiography in the Turkey population from cappadocia region. Eur J Dent. 2008;2:18.

27. Bruno G, De Stefani A, Balasso P, Mazzoleni S, Gracco A. Elongated styloid process: An epidemiological study on digital panoramic radiographs. J Clin Exp Dent. 2017;9(12):e1446.
28. Magat G, Ozcan S. Evaluation of styloid process morphology and calcification types in both genders with different ages and dental status. J Istanb Univ Fac Dent. 2017;51(2):29.

29. Öztunç H, Evlice B, Tatli U, Evlice A. Cone-beam computed tomographic evaluation of styloid process: a retrospective study of 208 patients with orofacial pain. Head Face Med. 2014;10(1):5.

30. Donmez M, Okumus O, Pekiner FN. Cone beam computed tomographic evaluation of styloid process: A retrospective study of 1000 patients. Eur J Dent. 2017;11(2):210.

31. Phulambrikar T, Rajeshwari A, Rao BB, Warhekar A, Reddy $P$. Incidence of elongated styloid process: a radiographic study. J Indian Acad Oral Med Radiol. 2011; 23 : S344-46.

32. Bagga MB, Kumar CA, Yeluri G. Clinicoradiologic evaluation of styloid process calcification. Imaging science in dentistry. 2012;42(3):155-161.

33. Ilguy M, Ilguy D, Guler N, Bayirli G. Incidence of the type and calcification patterns in patients with elongated styloid process. J Int Med Res. 2005;33:96-102.

34. Erol B. Radiological assessment of elongated styloid process and ossified stylohyoid ligament. J Marmara Uni Dent Fac. 1996;2:554-556.

How to cite this article: Kanjani V, Rani A, Kanjani D. Morphometric evaluation of the styloid process of the temporal bone as an aid in age and sex discrimination A retrospective digital panaromic study. Int J Maxillofac Imaging. 2018;4(4):118-121. 